\title{
Conformational Differences Unfold a Wide Range of Enterotoxigenic Abilities Exhibited by rNSP4 Peptides from Different Rotavirus Strains
}

\author{
Narayan P. Sastri ${ }^{1}$, Kiranmayee Pamidimukkala ${ }^{1}$, Jagannath R. Marathahalli ${ }^{1}$, Suguna Kaza ${ }^{2}$ and \\ C. Durga Rao ${ }^{*}, 1$ \\ ${ }^{I}$ Department of Microbiology \& Cell Biology, ${ }^{2}$ Molecular Biophysics Unit, Indian Institute of Science, Bangalore \\ 560012, India
}

\begin{abstract}
NSP4 has been recognized as the rotavirus-encoded enterotoxin. However, a few studies failed to support its diarrheagenic activity. As recombinant NSP4 (rNSP4) peptides of different lengths were used in the limited number of studies, a comparison of relative diarrheagenic potential of NSP4 from different strains could not be possible. To better understand the diarrheagenic potential of NSP4 from different strains, in this report we have evaluated the enterotoxigenic activity of the deletion mutant $\Delta \mathrm{N} 72$ that lacks the N-terminal 72 residues and the biologically relevant $\Delta \mathrm{N} 112$ peptide which when derived from SA11 rotavirus strain were previously shown to be highly diarrheagenic in newborn mice. Detailed comparative analysis of biochemical and biophysical properties and diarrheagenic activity of the recombinant $\Delta$ N72 peptides from seventeen different strains under identical conditions revealed wide differences among themselves in their resistance to trypsin cleavage, thioflavin T (ThT) binding, multimerization and conformation without any correlation with their diarrhea inducing abilities. These results support our previously proposed concept for the requirement of a unique conformation for optimal biological functions conferred by cooperation between the N- and C-terminal regions of the cytoplasmic tail.
\end{abstract}

Keywords: Rotavirus diarrhea, thioflavin $\mathrm{T}$, diarrheal dose $50\left(\mathrm{DD}_{50}\right)$, nonstructural protein 4, NSP4, virulence, multimerization, viral enterotoxin.

\section{INTRODUCTION}

The rotavirus nonstructural protein NSP4, encoded by genome segment 10, is 175 amino acids (aa) in length [1] and has been identified as the viral enterotoxin based on the ability of SA11-NSP4 to induce age-dependent diarrhea in suckling mice [2]. Several studies have revealed that the protein is structurally complex and functionally pleiotropic (Fig. 1A) [1, 3-6]. NSP4 is critical for rotavirus replication, morphogenesis and pathogenesis $[7,8]$. It has been reported to exist in multiple forms in the infected cells- as oligomers, higher molecular weight (HMW) complexes [9, 10] and endoplasmic reticulum (ER)- and cytoplasmic membrane-anchored forms [11-14]. Proteolytically-cleaved and secreted forms were also reported $[15,16]$. The ER-resident form is anchored through the Nterminal hydrophobic domains and the cytoplasmic tail (CT) of about 131 residues from the C-terminus exhibits all the known important properties associated with the protein including double-layered particle (DLP) binding [11, 12, 17-19] and diarrhea induction $[2,3]$. Recent studies have also shown that a pentalysine domain (PD) and amphipathic helical domain (AD) located between residue 55-90 together function as a viroporin domain (VD) [20] (Fig. 1A).

A peptide spanning residue 114-135 was reported to be about 800-fold less efficient in diarrhea induction compared to the full-length protein [2]. However, the sequence from aa $114-135$ is highly conserved among different symptomatic

*Address correspondence to this author at the Department of Microbiology \& Cell Biology, Indian Institute of Science, Bangalore 560012, India;

Fax: 91-80-23602697; E-mail: cdr@mcbl.iisc.ernet.in and asymptomatic strains and it alone unlikely determines the optimal diarrhea inducing potential of the protein. Further, a peptide from residue112-175, secreted from rotavirus infected cells, was reported to induce dosedependent diarrhea in suckling mice similar to the full-length protein [15]. Recently, we reported that the $\Delta \mathrm{N} 72$ deletion mutants from simian SA11 and bovine $\mathrm{Hg} 18$ strains were about 20-fold more efficient in diarrhea induction in newborn mice than that reported for the full-length protein, and exhibited efficient DLP-binding activity [3].

Rotaviruses exhibit a wide range of $\mathrm{DD}_{50}$ values in newborn mice [21-24]. Rotaviruses can be either symptomatic or asymptomatic, and in some cases NSP4 and a few other viral proteins could cooperatively determine virus virulence [25-32]. Analysis of NSP4 sequences from more than 175 strains failed to identify any residue or motif that could be associated with the virulence phenotype [33]. Mutations at positions 131, 135 and 138 which were reported to result in loss of a porcine rotavirus virulence and diarrheainducing ability of the protein [34], did not correlate with the attenuated phenotype of a vaccine strain [32] or the asymptomatic human or feline strains [35-37]. Further, a limited number of studies reported a lack of correlation between virulence of the rotavirus strain and the $\mathrm{DD}_{50}$ of the cognate NSP4 [22, 38, 39], some of which could be due to the use of rNSP4 mutants that varied widely in their length. Based on the analysis of a large number of mutants of the highly diarreagenic NSP4 from SA11 and $\mathrm{Hg} 18$ strains, we recently reported that the biological functions of rNSP4 proteins are dependent on a unique and complex 
(A)

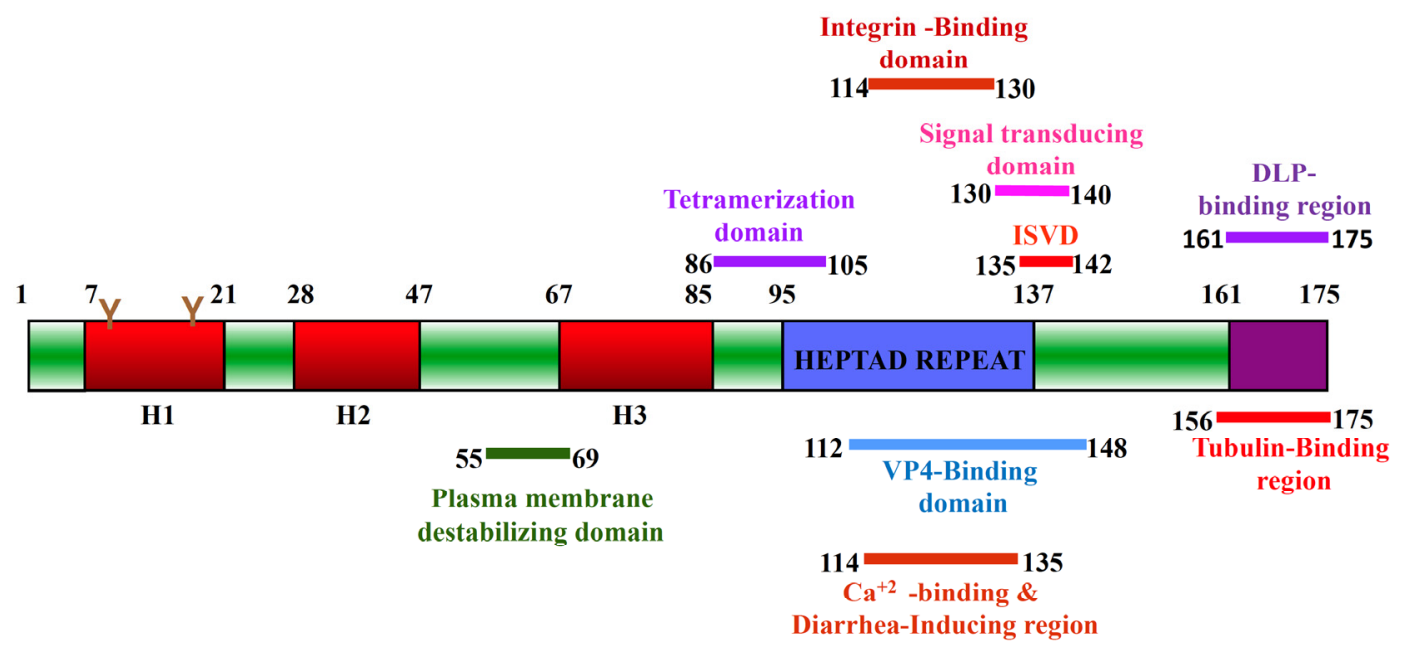

139

Flexible region

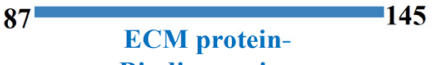

Binding region

(B)

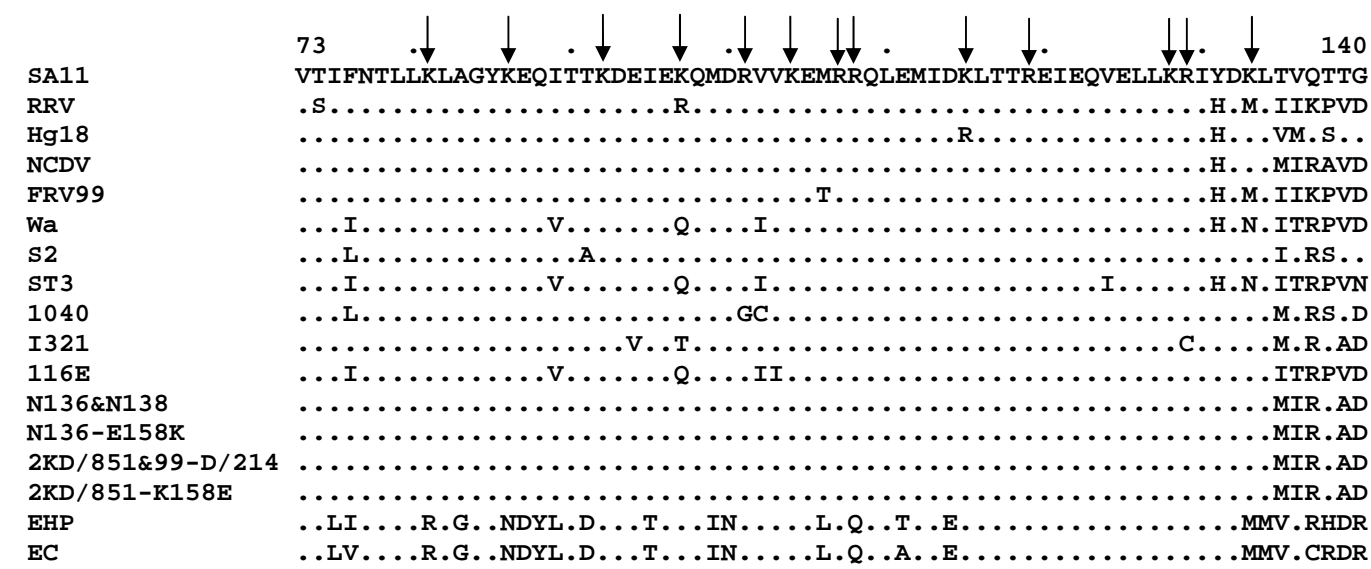

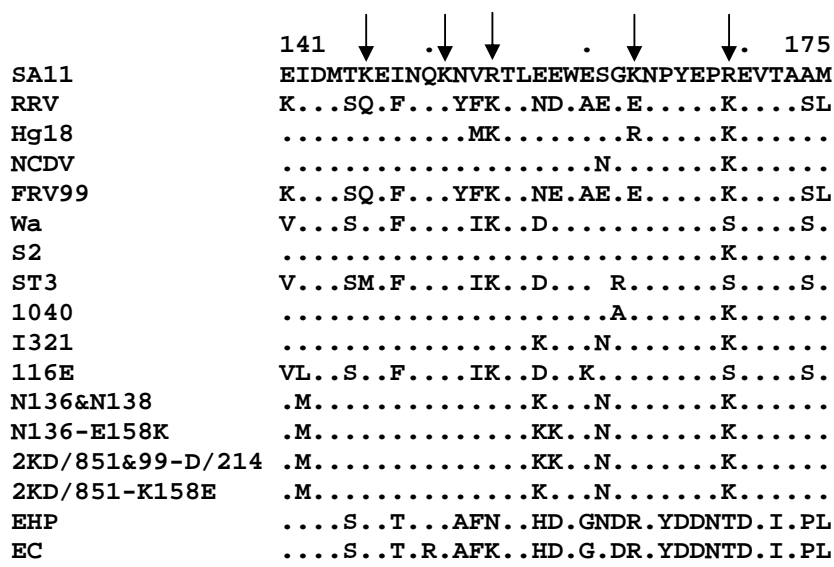

Fig. (1). (A). Schematic representation of the structural organization of rotavirus NSP4. H1, H2 and H3, N-terminal hydrophobic domains; ECM, Extra Cellular Matrix; ISVD, Interspecies variable domain; DLP, Double-layered particle, (B). Amino acid sequence alignment of the NSP4 $\Delta$ N72 region from different rotavirus strains used in this study. E158K and K158E represent the mutant NSP4 proteins generated by site-directed mutagenesis using PCR from the symptomatic (N136) and asymptomatic (2KD/851) Vellore strains, respectively. 
conformation of the cytoplasmic tail $[3,6]$. The reported wide variation in diarrhea inducing abilities of a few recombinant proteins could be attributed to improper conformation of the recombinant peptides $[22,38,39]$.

This study was undertaken to attempt to resolve the reported inconsistency in the diarrheagenic activity reported for a few rNSP4 peptides, that differed in length, by the analysis of the enterotoxigenic activity of a single polypeptide $(\Delta \mathrm{N} 72)$ of uniform size from a large number of strains. We have evaluated ThT binding, resistance to trypsin, multimerization/oligomerization and conformational properties of the proteins to understand if there is any correlation between any of these properties and their diarrheagenic potential.

\section{MATERIALS AND METHODOLOGY}

\section{Viruses and Cells}

The rotavirus strains, their $\mathrm{G}$ and $\mathrm{P}$ serotype/genotype associations and the host from which they were isolated are listed in Table 1. The Vellore neonatal strains were kindly provided by Dr. G. Kang, Christian Medical College, Vellore, India. Except for IS2, 1040, EHP, EC and Vellore strains, viruses were grown in MA104 cells.

Table 1. Rotavirus Strains Used in this Study and their G and P Serotype/Genotype Associations

\begin{tabular}{|c|c|c|c|}
\hline Strain & Serotype/Genotype & Host & Reference \\
\hline \hline SA11 & G3P[2] & Simian & \\
\hline RRV & G3P[3] & Rhesus & \\
\hline NCDV & G6P[1] & Bovine & \\
\hline Hg18 & G15P[21] & Bovine & {$[40]$} \\
\hline EHP & G3P[20] & Murine & \\
\hline EC & G3P[16] & Murine & \\
\hline FRV99 & G3 & Foal & Unpublished \\
\hline Wa & G1P[8] & Human & \\
\hline 1040 & G2P[4] & Human & {$[41,42]$} \\
\hline IS2 & G2P[4] & Human & {$[41,42]$} \\
\hline ST3 & G4P[6] & Human & \\
\hline I321 & G10P[11] & Human & {$[43]$} \\
\hline $116 E$ & G9P[11] & Human & {$[44]$} \\
\hline 2 KD/851 & G10P[11] & Human & {$[45]$} \\
\hline $99-D / 214$ & G10P[11] & Human & {$[45]$} \\
\hline N136 & G10P[11] & Human & {$[45]$} \\
\hline N138 & G10P[11] & Human & {$[45]$} \\
\hline
\end{tabular}

The rotavirus strains used in this study and their VP7 serotype and VP4 genotype associations, and the references for the relatively new and less studied viruses are indicated.

References are given only for the relatively less-studied strains.

\section{Cloning, Expression and Purification of Different NSP4 $\Delta$ N72 and $\Delta 112$ Peptides}

The genomic RNA from EC, EHP, IS2, 1040, I321 and Vellore strains was extracted from the fecal samples and that from others was isolated from infected cell culture supernatants as described previously [36, 43]. Cloning of the NSP4 gene, its $\Delta$ N72 region spanning aa 73 to 175 and generation of the pET22-NH vector for expression of proteins in fusion with an N-terminal His-tag have been described [3]. The $\Delta \mathrm{N} 112$ region was cloned using strainand position-specific primers. The nucleotide sequence of $\Delta \mathrm{N} 72$ and $\Delta \mathrm{N} 112$ in pBluescript KS + (pBS) or pET22-NH was determined using T7, M13 forward and/or reverse primers (Macrogen, Korea). All NSP4 $\Delta \mathrm{N} 72$ and $\Delta \mathrm{N} 112$ peptides expressed in E. coli BL21 (DE3) were highly soluble and were purified by $\mathrm{Ni}^{2+}$-NTA-agarose (QIAGEN) chromatography after binding in presence $0.5 \%$ NP-40 and washing extensively in its absence [3]. Purity of the proteins was confirmed by sodium dodecyl sulfate-polyacrylamide gel electrophoresis (SDS-PAGE) and mass spectrometry. Molecular masses of the peptides were determined by size exclusion chromatography (SEC) using Sephacryl S-200 column (GE Healthcare) on a Bio-Rad FPLC chromatography system as well as by mass spectrometry using Ultraflex time of flight mass spectrometer (Bruker Daltonics) [3, 46].

\section{Thioflavin T Fluorescence Assay}

$\triangle \mathrm{N} 72$ peptides dialyzed against a buffer containing 10 $\mathrm{mM}$ sodium phosphate $\mathrm{pH} 7.6$ and $100 \mathrm{mM} \mathrm{NaCl}$ at $100 \mu \mathrm{M}$ each of the protein and the dye were used. ThT-binding assays were performed by mixing $50 \mu 1$ of $60 \mu \mathrm{M}$ protein solution with $450 \mu 1$ of $10 \mu \mathrm{M}$ ThT. Readings were recorded in a Shimadzu RF-5301 PC spectrofluorometer at $25^{\circ} \mathrm{C}$. The excitation wave length was $450 \mathrm{~nm}$, and the emission was monitored between 450 and $600 \mathrm{~nm}$ [3, 47].

\section{Determination of Diarrhoeal Dose $50 \quad\left(D^{50}\right)$ of NSP4 $\Delta$ N72 and $\Delta 112$ Peptides}

Prior to animal experiments, the ThT binding ability of the $\Delta$ N72 peptides was evaluated [3]. Peptides exhibiting high ThT fluorescence were tested between 1 and 100 pmol and those showing highly reduced or lack of ThT binding were evaluated between $50 \mathrm{pmol}$ and $10 \mathrm{nmol}$ in 5-7 day-old $\mathrm{BALB} / \mathrm{c}$ mouse pups. The recombinant $\Delta \mathrm{N} 72$ and $\Delta \mathrm{N} 112$ peptides in $50 \mu \mathrm{l}$ of sterile PBS were administered intraperitoneally. $\mathrm{DD}_{50}$ and mean diarrheal scores, on a scale of 1-4, were determined as described [2,3]. At each dose, 8 mouse pups were used and the experiment was repeated three to four times. The fold efficiency of diarrhea induction of different NSP $4 \Delta$ N72 peptides was calculated with reference to the $\mathrm{DD}_{50}$ of $\mathrm{SA} 11 \Delta \mathrm{N} 72$ which exhibited the lowest value.

\section{Circular Dichroism (CD) Spectroscopy}

Secondary structural differences among different $\Delta$ N72 and $\Delta$ N112 peptides were examined employing Far UV-CD spectroscopy. The percent $\alpha$-helical, $\beta$-sheet and random conformation contents were determined using the $\mathrm{k} 2 \mathrm{~d}$ program [48]. CD spectra of the proteins, in $5 \mathrm{mM}$ sodium phosphate buffer $\mathrm{pH} 7.4$ containing $5 \mathrm{mM} \mathrm{NaCl}$, were recorded on a JASCO J-715 spectropolarimeter at a protein concentration of $10 \mu \mathrm{M}$ and the molar residue ellipticity was calculated as described [3].

Trypsin Resistance Analysis of Different NSP4 Proteins 
Purified $\Delta$ N72 peptides were digested with sequencing grade trypsin (Promega) at $37^{\circ} \mathrm{C}$, the trypsin-cleaved products were analyzed by Tricine-SDS-PAGE [49] followed by Coomassie Blue staining and the molecular masses of the cleaved products were determined by mass spectrometry as previously described [3]. Relative trypsin resistance on a scale of 0 to $100 \%$ was determined by densitometric measurement of intensities of bands corresponding to all the protected fragments of the helical region post $2 \mathrm{hr}$ incubation with respect to control peptide with 75 to $100 \%$ being highly resistant and 0 to $25 \%$ corresponding to undetectable level of protected fragments.

\section{RESULTS}

\section{Thioflavin $T$ Binding Ability of Different NSP4 $\Delta$ N72 Peptides}

Recently, we have shown that rNSP4 $\Delta$ N72 peptides from SA11 and $\mathrm{Hg} 18$ were highly diarrheagenic, formed highly ordered higher molecular weight (HMW) complexes, exhibited high $\alpha$-helical content, thioflavin $\mathrm{T}$ binding and resistance to trypsin of the region from residue 73-146 in contrast to a large number of their $\mathrm{N}$ - and C-terminal deletion mutants or amino acid (aa) substitution mutants [3, 6]. Mutations in $\Delta$ N72 affected the diarrhea-inducing and ThT-binding activities to different extents with $\mathrm{DD}_{50}$ increases ranging between 20-2080-fold $\left(\mathrm{DD}_{50} 0.05\right.$ to $>10$ nmol) $[3,6]$. These studies suggested a correlation between optimal ThT binding and efficient diarrhea induction and that efficient ThT binding is dependent on a unique conformation that is significantly affected by aa substitutions throughout the length of the peptide. Further, a specific conformation only in the ordered multimeric forms of SA11and $\mathrm{Hg} 18-\mathrm{NSP} 4 \Delta \mathrm{N} 72$, but not other HMW complexes of mutant NSP4 $\Delta$ N72 peptides, is recognized by ThT. Since NSP4s from different strains exhibit significant aa variations in the flexible C-terminal region of the cytoplasmic tail (CT) (Fig. 1B), it is likely that different NSP4 peptides would differ significantly from each other in their ThT binding property.

The observation that high ThT fluorescence exhibited by

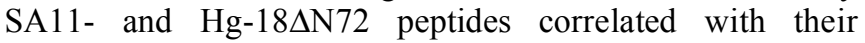
efficient diarrhea-inducing ability suggested that this property can be used to significantly reduce the number of mouse pups required to determine the $\mathrm{DD}_{50}$ of the large number of NSP4 peptides used in this study. Thus a protein showing high ThT binding need not be tested at high concentration and those that exhibit weak binding can be tested only at high concentration.

The $\Delta$ N72 peptides from 17 different human (symptomatic and asymptomatic) and animal strains (Table 1) were expressed, purified (Fig. 2A) and their ThT binding property was evaluated. As shown in Fig. (3), only I321-, SA11-, Hg18- and EHP- NSP4 $\triangle$ N72 peptides exhibited significant ThT fluorescence and those from all other strains showed either highly reduced or total lack of ThT binding. Of note, whilst NSP4 from the human asymptomatic strain I321 showed about 2.0-3.3-fold more ThT fluorescence than that of $\mathrm{Hg} 18$ and SA11, that from other human asymptomatic strains116E and ST3 exhibited highly reduced or negligible ThT fluorescence. The peptides from the two murine strains EHP and EC also varied significantly in their ThT binding ability. Thus in contrast to the previous observation with SA11- and Hg18- NSP4 $\Delta$ N72 peptides which exhibited high level of ThT binding, the present analysis using similar peptides from a large number of strains revealed that the ThT binding ability varied widely among different peptides.

\section{NSP4 $\Delta$ N72 and $\Delta$ N112 Peptides Exhibit Similar Pattern in their Diarrheagenic Abilities But with Different DD $_{50}$ Values}

Evaluation of the diarrhea inducing ability of $\Delta \mathrm{N} 72$ peptides from 17 different strains suggested that different NSP4 $\Delta$ N72 peptides used in this study can be identified as either efficient diarrhea inducers represented by SA11, Hg 18 and EHP which exhibited a low $\mathrm{DD}_{50}$ of $0.005-0.05 \mathrm{nmol}$, or inefficient/poor diarrhea inducers represented by other NSP4s exhibiting $\mathrm{DD}_{50}>0.05 \mathrm{nmol}$ (Table 2). Although the efficient diarrhea-inducing activity of the former group correlated, in general, with high ThT fluorescence and spontaneous diarrhea within 30 minutes of administration, the inefficient diarrhea inducers differed widely among themselves without any correspondence between ThT fluorescence and $\mathrm{DD}_{50}$ (Table 2). Further, NSP4s from symptomatic and asymptomatic strains could not be distinguished by their diarrhea inducing abilities. While the NSP4 peptides from human asymptomatic strains ST3, I321, and $116 \mathrm{E}$ exhibited $\mathrm{DD}_{50}$ values between 0.07 and $0.5 \mathrm{nmol}$, those from animal strains and human symptomatic strains (RRV, NCDV, FRV18, EC, and Wa, IS2 and 1040) showed $\mathrm{DD}_{50}$ in the range of 0.75 to $>10 \mathrm{nmol}$. Also, the $\Delta \mathrm{N} 72$ peptides from the Vellore symptomatic strains (N136 and N138) were about 33-fold less efficient in their ability to induce diarrhea in newborn mouse pups than those from the asymptomatic strains $2 \mathrm{KD} / 851$ and $99-\mathrm{D} / 214$. Of note, I321 NSP4 which bound ThT better than SA11 and Hg18 NSP $4 \Delta$ N72 peptides, was about 1000 -fold less efficient in diarrhea induction (Table 2). Whilst $\Delta$ N72 from SA11, Hg18 and EHP induced spontaneous diarrhea within 30-40 min of protein administration at the $\mathrm{DD}_{50}$ value with a mean diarrheal score of 3.2, the inefficient diarrheagenic peptides induced diarrheal stools at or below $\mathrm{DD}_{50}$ values between 1 and $2 \mathrm{hr}$ post administration only after gentle palpitation of the abdomen with mean diarrhoeal score of 2.0. Among the latter group, NSP4 from ST3 and NCDV exhibited comparatively lower $\mathrm{DD}_{50}(0.07$ and $0.075 \mathrm{nmol}$, respectively). While the peptides from RRV, Wa, equine strain FRV99 and the G2 strain 1040 showed 100-200-fold higher $\mathrm{DD}_{50}$, that from another G2 strain IS2 exhibited 1000fold higher $\mathrm{DD}_{50}$ than SA11-NSP4 $\Delta \mathrm{N} 72$ (Table 2). Of significance, the murine EC-NSP4 $\triangle \mathrm{N} 72$ failed to induce diarrhea even with $10 \mathrm{nmol}$ of the protein (precise $\mathrm{DD}_{50}$ not determined) compared to that of another murine strain EHP $(0.05 \mathrm{nmol})$. Though IS2-NSP4 $\Delta$ N72 peptide was very inefficient in diarrheagenic activity $(5.0 \mathrm{nmol})$ among the diarrheagenic $\Delta$ N72 peptides, it appears to be significantly better than the full-length proteins from avian strains (41-138 nmol) (Table 2) [23, 39]. 


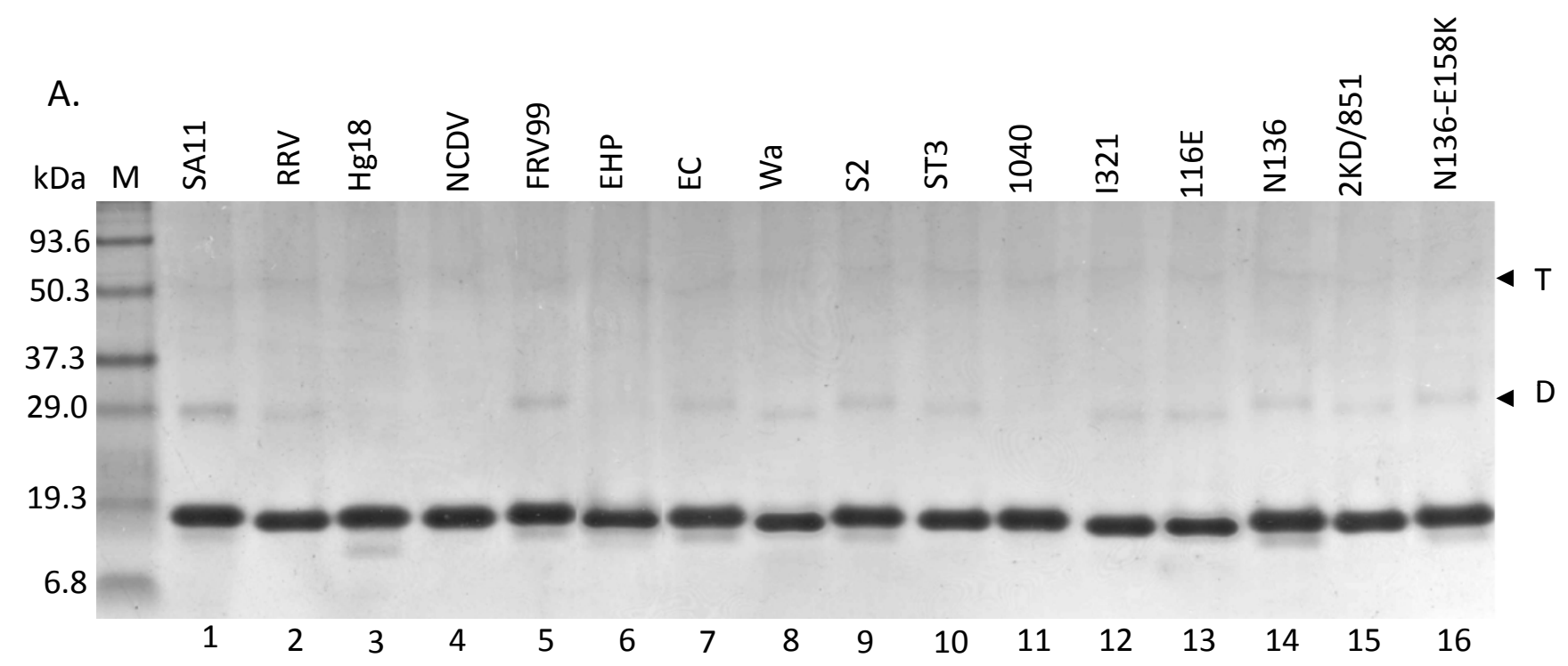

B.

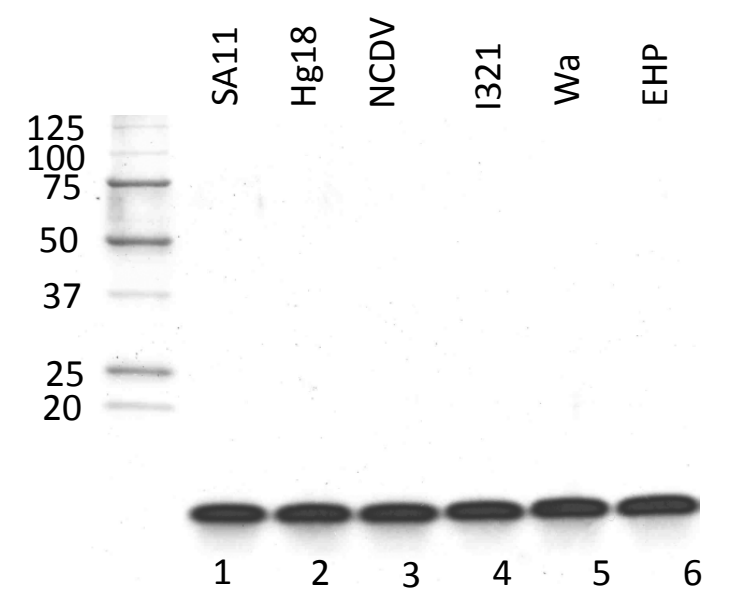

Fig. (2). Tricine-SDS-PAGE of NSP4 $\Delta$ N72 and $\Delta$ N112 polypeptides from different strains. 2A, Lanes 1-16 represent NSP4 of SA11, RRV, Hg18, NCDV, FRV99, EHP, EC, Wa, S2, ST3, 1040, I321, 116E, N136, 2KD/851 strains and N136-E158K mutant protein. Note that analysis of $\triangle \mathrm{N} 72$ from only 15 strains and one mutant protein is shown in the figure. Faint bands corresponding to dimmer (D) and tetramer (T) are shown by arrows. 2B, NSP4 $\Delta$ N112 peptides from 6 different strains. M, Pre-stained MW markers (Biorad).

Though $\Delta$ N72 from SA11 and $\mathrm{Hg} 18$ was very efficient in diarrhea induction, this mutant form of the protein is not detected in the virus infected cells. It is possible that the wide differences observed in the diarrheagenic properties of $\Delta$ N72 peptides from different strains could be a manifestation of the unnatural mutation. Since the full-length protein could not be expressed in E. coli and that expressed in insect cells was difficult to purify to homogeneity, we expressed and purified the recombinant $\Delta \mathrm{N} 112$ peptide (Fig. 2B), which is similar to the biologically active peptide secreted from the virus infected or gene-transfected cells [14], from six different strains (SA11, Hg18, NCDV, I321, EHP and $\mathrm{Wa}$ ) and determined their $\mathrm{DD}_{50}$ in newborn mouse pups. As shown in Table 2, though the pattern of diarrhea inducing ability of the $\Delta \mathrm{N} 112$ peptides from SA11, Hg18, NCDV, Wa and I321 was very similar to that of the corresponding $\Delta \mathrm{N} 72$ peptides, the former exhibited high
$\mathrm{DD}_{50}$ values than the latter. These results suggest that both $\Delta \mathrm{N} 72$ and $\Delta \mathrm{N} 112$ peptides from different strains exhibit very similar pattern in their diarrhea inducing properties, but differ in their relative diarrhea inducing efficiencies. The relatively high $\mathrm{DD}_{50}$ values exhibited by the $\Delta$ N112 peptides in comparison to those of $\Delta \mathrm{N} 72$ peptides could be attributed to their lack of the N-terminal amphipathic domain which was shown to potentiate the biological function of the protein $[3,20]$.

A Single aa Mutation in the Flexible C-Terminus of NSP4 from the Vellore Neonatal G10P[11]-Type Strains Correlates with Virus Virulence without Correspondence with the $\mathrm{DD}_{50}$ of the Cognate $\mathrm{rNSP}_{4} \Delta \mathrm{N} 72$

Recently, G10P [11] strains associated with symptomatic or asymptomatic infections in neonates in Vellore, India, were reported. However, sequence analysis of NSP4 from a 
Table 2. Comparative Analysis of Biochemical, Biophysical and Biological Properties of NSP4 N72 Polypeptides from 17 Different Rotavirus Strains

\begin{tabular}{|c|c|c|c|c|c|c|c|c|c|c|c|}
\hline \multirow{2}{*}{ Strain } & \multirow{2}{*}{ Preparation } & \multirow{2}{*}{$\mathrm{DD}_{50}(\mathrm{nmol})$} & \multirow{2}{*}{$\begin{array}{c}\text { Relative ThT } \\
\text { Binding }^{*}\end{array}$} & \multirow{2}{*}{$\alpha$-Helix } & \multirow{2}{*}{$\beta$-Sheet } & \multirow{2}{*}{ Random } & \multirow{2}{*}{$\begin{array}{l}\text { \% Trypsin } \\
\text { Resistance }\end{array}$} & \multicolumn{2}{|c|}{$\begin{array}{l}\text { Percentage } \\
\text { Multimer }\end{array}$} & \multicolumn{2}{|c|}{$\begin{array}{l}\text { Percentage } \\
\text { Oligomer }\end{array}$} \\
\hline & & & & & & & & $\begin{array}{c}2.0 \\
\mathrm{mg} / \mathrm{ml}\end{array}$ & $\begin{array}{c}0.6 \\
\mathrm{mg} / \mathrm{ml}\end{array}$ & $\begin{array}{c}2.0 \\
\mathrm{mg} / \mathrm{ml}\end{array}$ & $\begin{array}{c}0.6 \\
\mathrm{mg} / \mathrm{ml}\end{array}$ \\
\hline \multirow{2}{*}{ SA11 } & $\Delta \mathrm{N} 72$ & 0.005 & 308.72 & 61 & 7 & 32 & $75-100$ & 92 & 90 & 10 & 8 \\
\hline & $\Delta \mathrm{N} 112$ & 1.0 & ND & ND & ND & ND & ND & ND & ND & ND & ND \\
\hline \multirow{2}{*}{$\mathrm{Hg} 18$} & $\Delta \mathrm{N} 72$ & 0.006 & 484.89 & 62 & 6 & 31 & $75-100$ & 94 & 91 & 6 & 9 \\
\hline & $\Delta \mathrm{N} 112$ & 1.5 & ND & ND & ND & ND & ND & ND & ND & ND & ND \\
\hline \multirow{2}{*}{ EHP } & $\Delta \mathrm{N} 72$ & 0.05 & 217.42 & 57 & 8 & 35 & $75-100$ & 77 & 62 & 23 & 38 \\
\hline & $\Delta \mathrm{N} 112$ & $>6.0$ & ND & ND & ND & ND & ND & ND & ND & ND & ND \\
\hline $2 \mathrm{KD} / 851 \& 99-\mathrm{D} / 214$ & $\Delta \mathrm{N} 72$ & 0.06 & 33.65 & 41 & 17 & 42 & $75-100$ & 34 & 29 & 66 & 71 \\
\hline E158K mutant & $\Delta \mathrm{N} 72$ & 0.06 & 34.55 & 40 & 17 & 43 & $75-100$ & 35 & 30 & 65 & 70 \\
\hline ST3 & $\Delta \mathrm{N} 72$ & 0.07 & 1.71 & 59 & 8 & 33 & 50-75 & 90 & 85 & 10 & 15 \\
\hline \multirow{2}{*}{$\mathrm{NCDV}$} & \multirow{2}{*}{$\Delta \mathrm{N} 72 \Delta \mathrm{N} 112$} & 0.075 & 2.57 & 31 & 16 & 54 & $0-25$ & 61 & 2 & 39 & 98 \\
\hline & & 5.0 & ND & ND & ND & ND & ND & ND & ND & ND & ND \\
\hline \multirow{2}{*}{1321} & $\Delta \mathrm{N} 72$ & 0.5 & 1000 & 46 & 22 & 31 & $25-50$ & 80 & 75 & 20 & 25 \\
\hline & $\Delta \mathrm{N} 112$ & $>6.0$ & ND & ND & ND & ND & $\mathrm{ND}$ & ND & ND & ND & ND \\
\hline $116 \mathrm{E}$ & $\Delta \mathrm{N} 72$ & 0.5 & 104.36 & 57 & 9 & 34 & $25-50$ & 52 & 40 & 48 & 60 \\
\hline RRV & $\Delta \mathrm{N} 72$ & 0.75 & 119.87 & 48 & 18 & 35 & 50-75 & 95 & 72 & 5 & 28 \\
\hline 1040 & $\Delta \mathrm{N} 72$ & 0.75 & 1.47 & 30 & 26 & 44 & $0-25$ & 0 & 0 & 100 & 100 \\
\hline \multirow{2}{*}{ Wa } & $\Delta \mathrm{N} 72$ & 1.0 & 6.40 & 56 & 9 & 35 & $75-100$ & 38 & 30 & 62 & 70 \\
\hline & $\Delta \mathrm{N} 112$ & $>6.0$ & ND & ND & $\mathrm{ND}$ & ND & ND & ND & $\mathrm{ND}$ & ND & ND \\
\hline FRV99 & $\Delta \mathrm{N} 72$ & 1.0 & 24.15 & 40 & 17 & 44 & ND & ND & ND & 98 & 2 \\
\hline N136 \& N138 & $\Delta \mathrm{N} 72$ & 2.0 & 87.94 & 56 & 9 & 35 & $50-75$ & 41 & 37 & 59 & 63 \\
\hline K158E mutant & $\Delta \mathrm{N} 72$ & 2.0 & ND & ND & ND & ND & ND & ND & ND & ND & ND \\
\hline IS2 & $\Delta \mathrm{N} 72$ & 5.0 & 36.84 & 36 & 17 & 48 & $25-50$ & 12 & 5 & 88 & 95 \\
\hline $\mathrm{EC}$ & $\Delta \mathrm{N} 72$ & $>10.0$ & 49.97 & 39 & 17 & 44 & $75-100$ & 29 & 21 & 71 & 79 \\
\hline Strain & Preparation & $\mathrm{DD}_{50}(\mathrm{nmol})$ & \multicolumn{9}{|c|}{ Reference } \\
\hline SA11 & FL & 0.1 & \multicolumn{9}{|c|}{$[2]$} \\
\hline OSUv & FL & 0.175 & \multicolumn{9}{|c|}{$[33]$} \\
\hline OSUa & FL & $>0.5$ & \multicolumn{9}{|c|}{$[33]$} \\
\hline \multirow{3}{*}{ PO13 } & FL & 21 & \multirow{3}{*}{\multicolumn{9}{|c|}{$[22],[38]$}} \\
\hline & $\Delta \mathrm{N} 86$ & 1.0 & & & & & & & & & \\
\hline & $\Delta \mathrm{N} 109$ & 2.0 & & & & & & & & & \\
\hline TY3 & FL & 138 & \multicolumn{9}{|c|}{$[22],[38]$} \\
\hline TY1 & FL & 108 & \multicolumn{9}{|c|}{$[22],[38]$} \\
\hline Ch1 & FL & 41 & \multicolumn{9}{|c|}{$[22],[38]$} \\
\hline
\end{tabular}

$\mathrm{DD}_{50}$ values of NSP4 $\Delta \mathrm{N} 72$ and $\Delta \mathrm{N} 112$ polypeptides from different rotavirus strains from different species in newborn mice are shown. The DD 50 values previously reported by others for different NSP4 peptides are also shown. The relative ThT fluorescence emission values are with reference to the lowest-binding $\Delta \mathrm{N} 72$ from strain 1040 . The conformational contents, relative resistance to trypsin digestion, multimerizatio/oligomerization properties of different NSP4 $\Delta$ N72 peptides are provided. Note the asymptomatic strains from which the NSP4 is derived for this study are indicated in yellow shade. The level of efficiency of the proteins in each of the properties is classified into 4 grades in different colour shades. Pink colour refers to either highest efficiency or highest values. Green, gray and red shades denote the decreasing levels of efficiency or the values in the properties. Though efficient diarrhea inducers exhibit high ThT fluorescence, $\alpha$-helical content, trypsin resistance and efficient multimerization, note a general lack of correlation among the properties of other proteins. FL, full length, ND, Not Determined, OSUv and OSUa refer to OSU virulent and avirulent strains, respectively. E158K and K158E mutant proteins are described in the legend to Fig. (1B). 
few isolates failed to differentiate the virulent from the avirulent strains [45]. Sequence analysis, in our laboratory, of NSP4 $\Delta$ N72 from two symptomatic Vellore isolates (N136 and N138) for which the sequence was not reported, and two asymptomatic isolates $(2 \mathrm{KD} / 851$ and $99-\mathrm{D} / 214)$ for which the sequence was available, revealed a single aa difference at position $158(\mathrm{E} 158 \mathrm{~K})$ between the virulent and avirulent pairs. While the symptomatic isolates contained Glu at this position, the asymptomatic strains possessed Lys (Fig. 1B). Only Glu was reported at position 158 in both symptomatic and asymptomatic strains [45]. To understand if the virulence phenotype of the Vellore strains correlates with the diarrheagenic activity of cognate NSP4, the $\mathrm{DD}_{50}$ of $\Delta \mathrm{N} 72$ peptides from symptomatic and asymptomatic isolates in suckling mice was determined. Unexpectedly, NSP4 $\Delta$ N72 peptide from the symptomatic isolates N136 and N138 exhibited $\mathrm{DD}_{50}(2.0 \mathrm{nmol})$ that was about 33 -fold higher than that of the asymptomatic isolates $2 \mathrm{KD} / 851$ and $99-\mathrm{D} / 214$ (0.06 nmol). Association of the E158K mutation with altered diarrhea induction was further evident from the $\mathrm{DD}_{50}$ values of the $\mathrm{E} 158 \mathrm{~K}$ and $\mathrm{K} 158 \mathrm{E}$ mutant peptides which were indistinguishable from those of the peptides from asymptomatic and symptomatic strains, respectively (Table 2). Of note, N136- $\Delta \mathrm{N} 72$ consistently showed $>50 \%$ higher ThT fluorescence of that of $2 \mathrm{KD} / 851$, though significantly less than that showed by SA11 and Hg18, (Fig. 3) but was relatively inefficient in diarrhea induction than $2 \mathrm{KD} / 851$.
$\Delta$ N72 Peptides from Different Strains Differ Significantly in their Resistance to Cleavage by Trypsin

Though ThT is frequently used to detect $\beta$-sheet structures in amyloid fibrils and ordered polymeric proteins $[50,51]$, studies on acetylcholinesterase [52] revealed that ThT binds efficiently to the peripheral ligand binding site which lacks $\beta$-sheet structures characteristic of amyloid protein. Though the precise nature of interaction is not understood, these as well as our results $[3,6]$ suggested that ThT could bind to proteins independent of the amyloid $\beta$ sheet structures and that different amino acid substitution and deletion mutant NSP $4 \Delta \mathrm{N} 72$ peptides differ significantly in their conformation.

The $\Delta$ N72 peptide region from different strains contains 17 trypsin cleavage sites that are conserved among the strains (Fig. 1B). Previously, we have shown that single amino acid substitutions in the CT of the highly diarrheagenic SA11-NSP4 $\Delta$ N72 affected its diarrhea inducing ability and resistance to trypsin digestion [3]. Since different NSP4s significantly differ in their sequence in the unstructured C-terminal region, it is likely that NSP4s from different strains would vary in their susceptibility to trypsin cleavage. As shown in Fig. (4), the order of trypsin resistance on a scale of 0 to 100 (100 being the highest) was SA11, Hg18, Wa, EHP, EC, 2KD/851 and N136-E158K (75$100 \%)>$ ST3, RRV and N136 (50 to 75\%) > IS2, I321, 116E $(25$ to $50 \%)>$ NCDV and $1040(0$ to $25 \%)$, with the SA11 group being highly resistant and NCDV group being

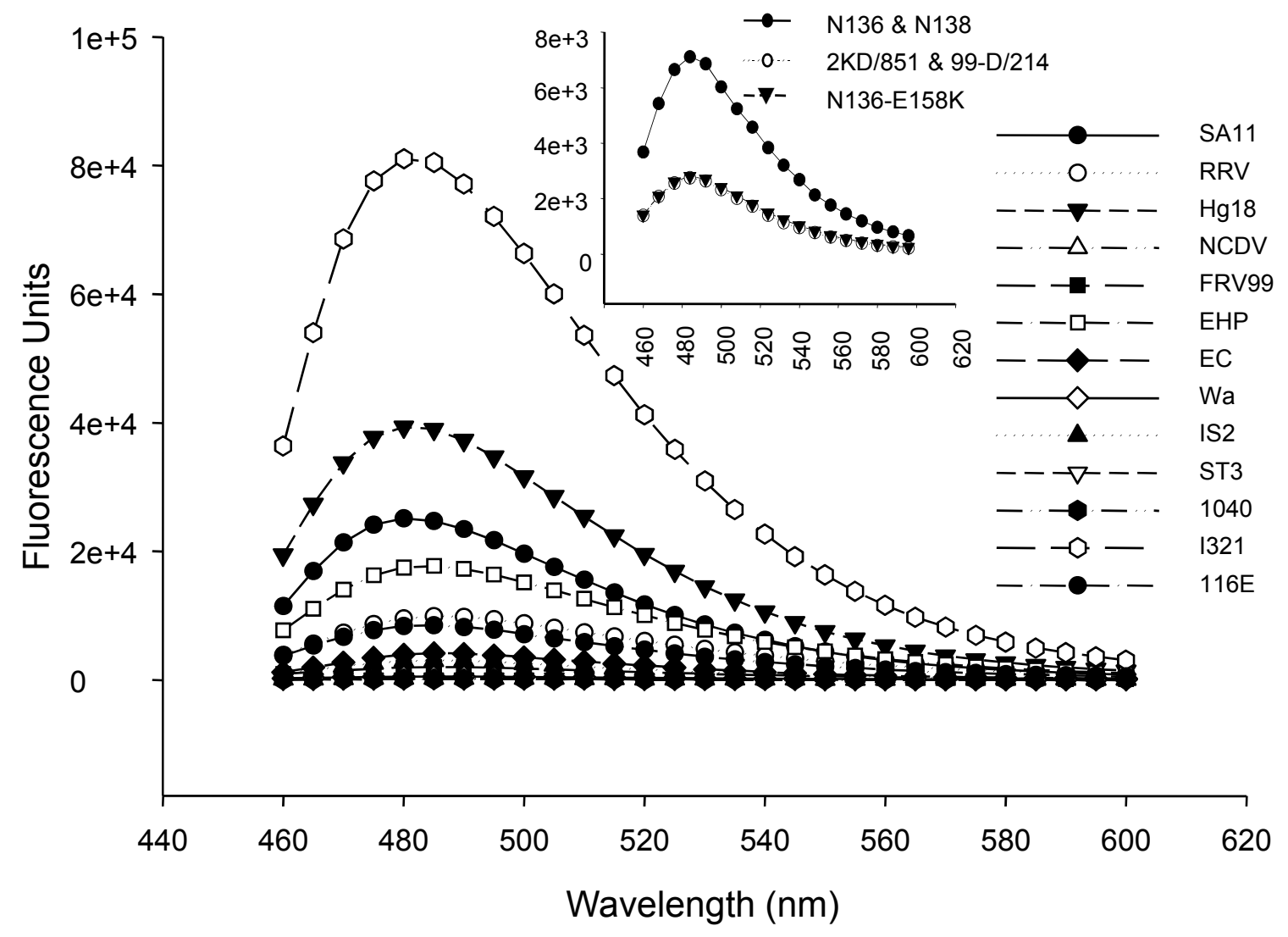

Fig. (3). ThT fluorescence spectra of different NSP4 $\Delta$ N72 proteins. The figure insert shows the ThT fluorescence spectra of NSP4 $\Delta$ N72 from the Vellore symptomatic (N136) and asymptomatic $(2 \mathrm{KD} / 851)$ strains and E158K mutant protein generated from N136. Note that the fluorescence spectrum of the mutant protein is identical to that from the asymptomatic strain $2 \mathrm{KD} / 851$. 


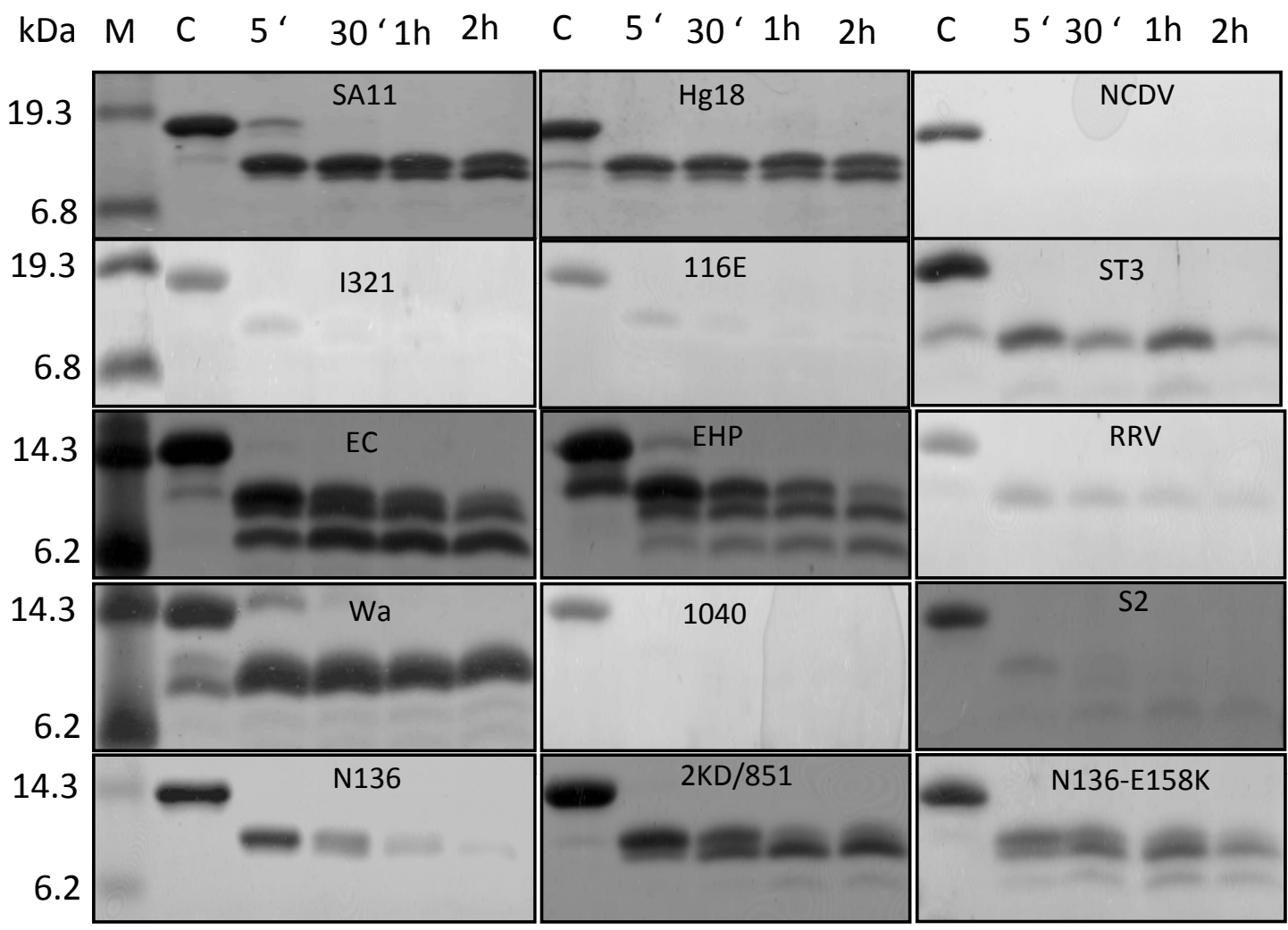

Fig. (4). Relative trypsin Resistance of NSP4 $\Delta$ N72 proteins from different strains. The relative resistance to trypsin of the region from residue 72-146 among the different $\Delta$ N72 peptides is indicated on a scale of 0-100. M, Top two panels- Prestained MW markers (Biorad), bottom three panels- Low MW range markers (GIBCO-BRL).

extremely susceptible. While $\Delta \mathrm{N} 72$ from SA11, Hg18 and WA yielded a $9.95 \mathrm{kDa}$ stable fragment, that from the murine strains yielded additional smaller stable fragments (Fig. 4). Further, the non-diarrheagenic EC-NSP4 4 N72 was as resistant to trypsin as EHP-NSP4 $\Delta$ N72. It may be noted that NSP4s from the murine strains exhibit high sequence divergence compared to that of other group A rotaviruses and form a distinct genetic group [22] (Fig. 1B). Of significance, $\Delta \mathrm{N} 72$ from the symptomatic strain N136 was highly susceptible to trypsin and about 33-fold less diarrheagenic compared to that from the asymptomatic strain $2 \mathrm{KD} / 851$ or the N136-E158K mutant in spite of the protein from N136 exhibiting relatively higher ThT fluorescence (Figs. 3, 4 and Table 2).

\section{rNSP4 $\Delta$ N72 Peptides from Different Strains Differ in their Conformation and Multimerization Properties}

The wide differences in ThT binding and susceptibility to trypsin digestion suggest conformational differences among the recombinant $\Delta$ N72 peptides from different strains. CD spectroscopic studies were employed to confirm this prediction. As shown in Fig. (5) and Table 2, all the peptides exhibited highly negative $\mathrm{CD}$ spectral values as expected suggesting that they contained the expected coiled coil domain (CCD) and the highly diarrheagenic SA11-, Hg18and EHP- $\triangle$ N72 peptides consistently showed high $\alpha$-helical content compared to majority of the peptides as observed earlier [3]. Thus while high $\alpha$-helical content correlated well with the low $\mathrm{DD}_{50}$ values of the efficient diarrhea inducers, the inefficient diarrhea inducers differed significantly among themselves in their conformation contents without correlation to their relative $\mathrm{DD}_{50}$ values. For example, while NSP4 4 N72 from Wa, ST3, 116E, N136 and N138 exhibited about $56-58 \%$, that from all other strains showed only 30 $48 \% \alpha$-helical content. Generally, proteins exhibiting high $\alpha$-helicity contained less than $9 \% \beta$-sheet content and those with low $\alpha$-helical content showed between 16 and $26 \%$. NCDV-NSP4 $\Delta$ N72 differed from all others as it failed to bind ThT and exhibited very high (54\%) random conformation content in contrast to that of other proteins which ranged between 32 and $44 \%$. The SA $11 \Delta \mathrm{N} 112$ peptide contained very low $\alpha$-helical content compared to the corresponding $\Delta \mathrm{N} 72$ peptide. Hence the secondary structural contents of $\Delta \mathrm{N} 112$ peptides from other strains were not evaluated.

Conformational differences appeared to reflect the ordered multimerization ability of the different recombinant proteins. We recently showed that the highly diarrheagenic NSP4 $\Delta$ N72 from SA11 and $\mathrm{Hg} 18$ existed in HMW complexes in E. coli, and that the purified protein formed highly ordered multimers and mutations in the $\mathrm{N}$ - or $\mathrm{C}$ terminal regions significantly perturbed the conformation and equilibrium between the multimeric and oligomeric forms to different extents $[3,6]$. As shown in Table 1, while the highly diarrheagenic SA11- and $\mathrm{Hg} 18-\Delta \mathrm{N} 72$ peptides exhibited efficient multimerization even at low concentration as reported earlier [3], all other $\Delta$ N72 peptides differed widely in their multimerization property. Some showed concentration-dependent multimerization (EHP and RRV), whereas others either existed predominantly in oligomeric form or failed to multimerize even at high concentration 


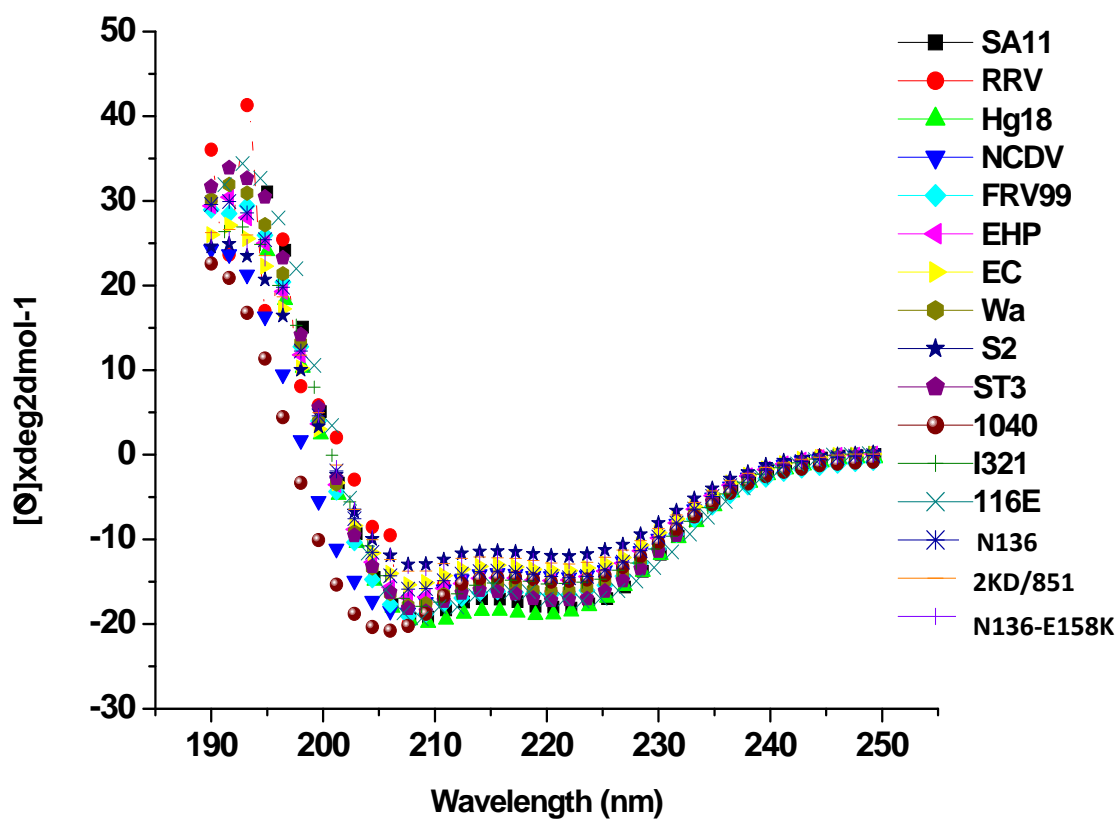

Fig. (5). Secondary structure analysis of recombinant NSP4 $\Delta$ N72 proteins by Far UV-CD spectroscopy. Purified NSP4s exhibit coiled coil structures as revealed by the highly negative CD spectral values but with significant secondary structural differences among themselves.

(Table 2). Though the rNSP4 $\Delta$ N72 from the symptomatic and asymptomatic Vellore strains differing in a single amino acid showed comparable multimerization/oligomerization properties, they differed significantly in their ThT binding, trypsin resistance and conformation contents. NCDVNSP4 $\triangle$ N72 though failed to multimerize at low concentration, about $60 \%$ existed as HMW form at high concentration. Interestingly, its diarrhea-inducing ability showed a sharp decline below $\mathrm{DD}_{50}$ value, which probably correlates with the extreme instability of the oligomers at low concentration as seen by the broad peak in SEC (data not shown).

\section{DISCUSSION}

Our recent studies based on SA11-and Hg18- $\Delta$ N72 peptides and their mutants suggested that efficient diarrhea induction is correlated with high ThT fluorescence, trypsin resistance, $\propto$-helical content and/or ordered multimerization $[3,6]$. However, the present analysis of different properties of NSP $4 \Delta \mathrm{N} 72$ peptides on a wider scale revealed that efficient diarrhea inducers exhibited high-level of ThT binding, $\alpha$-helical content, trypsin resistance, and multimerization. However, no such correlation between the relative $\mathrm{DD}_{50}$ values of the inefficient diarrheagenic peptides and any of the studied properties was observed. (Table $\mathbf{2}$, Figs. 3-5). Of interest, $\Delta \mathrm{N} 72$ peptides from asymptomatic strains differed significantly among themselves in their properties. Whilst ST3-NSP4 $\Delta$ N72 failed to bind ThT and exhibited $\mathrm{DD}_{50}$ of $0.07 \mathrm{nmol}$, that of I321, though exhibited high ThT fluorescence, was about 7 fold less efficient in diarrhea induction than the former. 116E $\Delta \mathrm{N} 72$, though showed $\mathrm{DD}_{50}$ similar to that of I321, exhibited negligible ThT binding. Also, the $\mathrm{DD}_{50}$ of $\Delta \mathrm{N} 72$ peptides from the asymptomatic strains was either very similar to, or significantly lower than that of some of the symptomatic strains. Further, the NSP4 $\Delta \mathrm{N} 72$ peptide from the symptomatic Vellore strains N136 and N138 was about 33- fold less efficient than that of the asymptomatic strains $2 \mathrm{KD} / 851$ and $99-\mathrm{D} / 214$ in spite of the former showing higher $\alpha$-helical content and ThT binding. Linear regression analysis of the data from Table 2 using $\mathrm{DD}_{50}$ as dependent variable and ThT fluorescence, $\propto$-helical content, trypsin resistance or percent multimerization as independent variables conclusively revealed a lack of correspondence between diarrheagenic activity and any of the biochemical and biophysical properties (data not shown).

Though it may be argued that $\Delta$ N72 peptide does not correspond to the full-length protein or a biologically relevant peptide in the infected cells, it is the longest and highly diarrheagenic peptide from SA11 and Hg18 that could be purified to homogeneity in large quantities from $E$. coli [3]. Present studies using the biologically relevant $\Delta \mathrm{N} 112$ peptides revealed that both $\Delta \mathrm{N} 72$ and $\Delta \mathrm{N} 112$ peptides from different strains exhibit similar pattern of diarrhea inducing properties though differ in the relative range of their $\mathrm{DD}_{50}$ values. The $\Delta \mathrm{N} 72$ peptide from SA11 and $\mathrm{Hg} 18$ is about 20 and 200 -fold more efficient in diarrhea induction than that reported for the full-length protein and the secreted $\Delta \mathrm{N} 112$ peptide $[2,3,15]$, respectively in newborn mice and exhibits efficient DLP-binding activity suggesting that this region exhibits optimal biological properties associated with fulllength protein. The observation that $\Delta \mathrm{N} 112$ peptide was less efficient than $\Delta \mathrm{N} 72$ further supports our previous observation that both the $\mathrm{N}$-terminal $\mathrm{AD}$ and $\mathrm{C}$-terminal flexible regions are important for optimal biological functions of the protein $[3,6]$. A recent report of the viroporin activity of the $\mathrm{N}$-terminal region from residue 55 90 further supports this observation [20]. Since full-length NSP4 could neither be expressed in E. coli due to the presence of hydrophobic domains at the $\mathrm{N}$-terminus nor could that expressed in insect cells be purified to homogeneity [2], different studies used deletion mutants that varied widely in their length and/or the presence or absence of a tag at the N-terminus which might have contributed to 
the wide differences in the $\mathrm{DD}_{50}$ values reported in the limited number of studies [2, 3, 15, 23, 39]. Results in our laboratory indicated that presence of a His-tag at the $\mathrm{N}$ terminus of SA11- and $\mathrm{Hg} 18-\Delta \mathrm{N} 72$ did not affect its biological function.

Recent studies from our laboratory $[3,6]$ also suggested that sequence variations observed in the flexible C-terminus compared to the other regions of NSP4s in different strains [33] (Fig. 1B) would affect conformation, ThT binding and biological properties of the recombinant protein. The significant differences in ThT binding, resistance to trypsin digestion, conformation and $\mathrm{DD}_{50}$ values exhibited by the recombinant proteins from the symptomatic and asymptomatic G10P [11] strains that differed at a single amino acid position 158 in the flexible $\mathrm{C}$-terminal region strongly supports this hypothesis. Further, it may be noted that the EC-NSP4 differs from that of EHP at four positions 137, 150, 154 and 161 in the unstructured C-terminus (Fig. 1B). The observation that $\mathrm{rNSP} 4 \Delta \mathrm{N} 72$ peptides from the murine EHP and EC strains exhibit contrasting diarrhea inducing properties in spite of both viruses being highly virulent in the homologous host strongly suggests a conformational conundrum to the differences in the biological function of the recombinant polypeptides. In the infected cells, NSP4 interaction with other viral $[1,9,20]$ and cellular proteins $[53-57,64]$ might facilitate conformational maturation and the multitude of its biological functions $[2,6,53,54,57-67]$. The present studies also suggest that mutations in different NSP4s that could severely affect their biological functions would vary from strain to strain and depend on the overall sequence context of the complete $\mathrm{CT}$, and that $\mathrm{rNSP} 4 \mathrm{~s}$, irrespective of their origin, would exhibit $\mathrm{DD}_{50}$ values with inconsistent correlation to the virulence of their virus strains. In this context, our earlier observation that the biological properties of the highly diarrheagenic SA11-NSP4 $\Delta$ N72 are dependent on a unique and complex conformation in the cytoplasmic tail, mediated by cooperation between the N-terminal amphipathic domain and the extreme C-terminus, is of relevance. The wide variation in conformation among the different peptides, supported by the wide range of differences in susceptibility to trypsin cleavage, ThT binding and multimerization, strongly suggests that unlike the highly enterotoxigenic rNSP4 peptides from SA11 and $\mathrm{Hg} 18$, those from majority of the strains fail to attain the proper conformation required for optimal diarrheagenic function.

\section{ACKNOWLEDGEMENTS}

Financial support from the Indian Council of Medical Research and the Structural Genomics program under the Genomics Initiative at the Indian Institute of Science funded by the Department of Biotechnology, Indian Council of Medical Research, Government of India is acknowledged. We gratefully acknowledge the use of mass spectrometry and CD facilities in the Molecular Biophysics Unit and the $\mathrm{CD}$ facility in the Department of Biochemistry at the Indian Institute of Science. Technical assistance from Mr. Senthil Kumar is acknowledged.

\section{REFERENCES}

[1] Estes MK. In: Knipe DM, Howley PM, Griffin DE, Lamb RA,. Martin MA, Roizman B, Straus SE, Eds. Fields Virology, $4^{\text {th }}$ ed, vol. 2. Philadelphia; Lippincott Williams and Wilkins 2001; 174785 .

[2] Ball JM, Tian P, Zeng CQ-Y, Morris AP, Estes MK. Agedependent diarrhea induced by a rotavirus nonstructural glycoprotein. Science 1996; 272 : 101-4.

[3] Jagannath MR, Kesavulu MM, Deepa R, et al. N- and C-terminal cooperation in rotavirus enterotoxin: novel mechanism of modulation of the properties of a multifunctional protein by a structurally and functionally overlapping conformational domain. J Virol 2006; 80: 412-25.

[4] Taylor JA, O'Brien JA, Yeager M. The cytoplasmic tail of NSP4, the endoplasmic reticulum-localized non-structural glycoprotein of rotavirus, contains distinct virus binding and coiled coil domain. EMBO J 1996; 15: 4469-76.

[5] Deepa R, Rao CD, Suguna K. Structure of the extended diarrheainducing domain of rotavirus enterotoxigenic protein NSP4. Arch Virol 2007; 152: 847-59.

[6] Deepa R, Sastri NP, Rao CD et al. The flexible C-terminus of the rotavirus nonstructural protein NSP4 is an important determinant of its biological properties. J Gen Virol 2008; 89: 1485-96.

[7] Lopez T, Camacho M, Zayas M, et al. Silencing the morphogenesis of rotavirus. J Virol 2005; 79: 184-92.

[8] Silvestri LS, Tortorici MA, Vasquez-Del Carpio R, Patton JT. Rotavirus glycoprotein NSP4 is a modulator of viral transcription in the infected cell. J Virol 2005; 79: 15165-74.

[9] Maass DR. Atkinson PH. Rotavirus proteins VP7, NS28, and VP4 form oligomeric structures. J Virol 1990; 64: 2632-41.

[10] Taylor JA, Meyer JC, Legge MA, et al. Transient expression and mutational analysis of the rotavirus intracellular receptor: the Cterminal methionine residue is essential for ligand binding. J Virol 1992; 66: 3566-72.

[11] Bergman CC, Mass D, Poruchynsky M, Atkinson PH, Bellamy AR. Topology of the nonstructural rotavirus receptor glycoptrotein NS28 in the rough endoplasmic reticulum. EMBO J 1989; 8: 1695703.

[12] Chan WK, Au KS, Estes MK. Topology of the simian rotavirus nonstructural glycoproteins (NS28) in the endoplasmic reticulum membrane. Virology 1988; 164: 435-42.

[13] Storey SM, Gibbons TF, Williams CV, Parr RD, Schroeder F, Ball JT. Full-length, glycosylated NSP4 is localized to plasma membrane caveolae by a novel raft isolation technique. J Virol 2007; 81: 5472-83

[14] Gibbons TF, Storey SM, Williams CV, et al. Rotavirus NSP4: Cell type-dependent transport kinetics to the exofacial plasma membrane and release from intact infected cells. Virol J 2011, 8: 278 .

[15] Zhang M, Zeng CQ, Morris AP, Estes MK. A functional NSP4 enterotoxin peptide secreted from rotavirus-infected cells. J Virol 2000; 74: 11663-70.

[16] Bugarcic A, Taylor JA. Rotavirus nonstructural glycoprotein NSP4 is secreted from the apical surfaces of polarized epithelial cells. J Virol 2006; 80: 12343-9.

[17] Au K.-S, Mattion NM, Estes MK. A subviral particle binding domain on the rotavirus nonstructural glycoprotein NS28. Virology 1993; 194: 665- 73 .

[18] O'Brien JA, Taylor JA, Bellamy AR. Probing the structure of rotavirus NSP4: a short sequence at the extreme $\mathrm{C}$ terminus mediates binding to the inner capsid particle. J Virol 2000; 74: 5388-94.

[19] Taylor JA, O'Brien JA, Lord VJ, Meyer JC, Bellamy AR. The RER- localized rotavirus intracellular receptor: A truncated purified soluble form is multivalent and binds virus particles. Virology 1993; 194: 807-14.

[20] Hyser JM, Collinson-Pautz MR, Utama B, Estes MK. Rotavirus disrupts calcium homeostasis by NSP4 viroporin activity. mBio 2010, 1: e00265-10.

[21] Burns JW, Krishnaney AA, Vo PT, Rouse RV, Anderson LJ, Greenberg HB. Analyses of homologous rotavirus infection in the mouse model. Virology 1995; 207: 143-53.

[22] Horie Y, Nakagomi O, Koshimura Y, et al. Diarrhea induction by rotavirus NSP4 in the homologous mouse model system. Virology 1999; 262: 398-407.

[23] Mori Y, Sugiyama M, Takayama M, Atoji Y, Masegi T, Minamoto N. Avian-to-mammal transmission of an avian rotavirus: Analysis of its pathogenicity in a heterologous mouse model. Virology 2001; 288: $63-70$. 
[24] Ramig RF. The effects of host age, virus dose, and virus strain on heterologous rotavirus infection of suckling mice. Microb Pathog 1988; 4: 189-202.

[25] Bridger JC, Burke B, Beards GM, Desselberger U. The pathogenecity of two porcine rotaviruses differing in their in vitro growth characteristics and gene 4. J Gen Virol 1992; 73: 3011-5.

[26] Broome RL, Vo PT, Ward RL, Clark HF, Greenberg HB. Murine genes encoding outer capsid proteins VP4 and VP7 are not major determinants of host restriction and virulence. J Virol 1993; 67: 2448-55.

[27] Burke B, Desselberger U. Rotavirus pathogenicity. Virology 1996; 218: 299-305.

[28] Hoshino Y, Saif LJ, Kang SY, Sereno MM, Chen WK, Kapikian AZ. Identification of group A rotavirus genes associated with virulence of a porcine rotavirus and host range restriction of a human rotavirus in the gnotobiotic piglet model. Virology 1995; 209: 274-80.

[29] Kirkwood CD, Coulson BS, Bishop RF. G3P2 rotaviruses causing diarrheal disease in neonates differ in VP4, VP7 and NSP4 sequence from G3P2 strains causing asymptomatic neonatal infection. Arch Virol 1996; 141: 1661-76.

[30] Offit PA, Blavat G, Greenberg HB, Clark HF. Molecular basis for rotavirus virulence: role of gene segment 4. J Virol 1986; 57: 46-9.

[31] Mori Y, Borgan MA, Takayama M, Ito N, Sugiyama M, Minamoto $\mathrm{N}$. Roles of outer capsid proteins as determinants of pathogenicity and host range restriction of avian rotaviruses in a suckling mouse model. Virology 2003; 316: 126-34.

[32] Ward RL, Mason BB, Bernstein DI, et al. Attenuation of a human rotavirus vaccine candidate did not correlate with mutations in the NSP4 gene. J Virol 1997; 71: 6267-70.

[33] Lin SL, Tian P. Detailed computational analysis of a comprehensive set of group A rotavirus NSP4 proteins. Virus Genes 2003; 26: 271-82.

[34] Zhang M, Zeng CQ, Dong Y, et al. Mutations in rotavirus nonstructural glycoprotein NSP4 are associated with altered virus virulence. J Virol 1998; 72: 3666-72.

[35] Chang KO, Kim YJ, Saif LJ. Comparisons of nucleotide and deduced amino acid sequences of NSP4 genes of virulent and attenuated pairs of group A and C rotaviruses. Virus Genes 1999; 18: 229-33.

[36] Jagannath MR, Vethanayagam RR, Reddy BSY, Raman S, Rao $\mathrm{CD}$. Characterization of human symptomatic rotavirus isolates MP409 and MP480 having 'long' RNA electropherotype and subgroup I specificity, highly related to the P6[1], G8 type bovine rotavirus A5, from Mysore, India. Arch Virol 2000; 145: 1339-157.

[37] Oka T, Nakagomi T, Nakagomi O. A lack of consistent amino acid substitutions in NSP4 between rotaviruses derived from diarrheal and asymptomatically infected kittens. Microbiol Immunol 2001; 45: 173-7.

[38] Angel J, Tang B, Feng N, Greenberg HB, Bass D. Studies of the role for NSP4 in the pathogenesis of homologous murine rotavirus diarrhea. J Infect Dis 1998; 177: 455-8.

[39] Mori Y, Borgan MA, Ito N, Sugiyama M, Minamoto N. Diarrheainducing activity of avian rotavirus glycoproteins, which differ greatly from mammalian rotavirus NSP4 glycoproteins in deduced amino acid sequence in suckling mice. J Virol 2002; 76: 5829-34.

[40] Rao CD, Gowda K, Reddy BSY. Sequence analysis of VP4 and VP7 genes of nontypeable strains identifies a new pair of outer capsid proteins representing novel $\mathrm{P}$ and $\mathrm{G}$ genotypes in bovine rotaviruses. Virology 2000; 276: 104-13.

[41] Aijaz S, Gowda K, Jagannath HV, et al. Epidemiology of symptomatic rotaviruses in Bangalore and Mysore, India, from 1988 to 1994 as determined by electropherotypes, subgroup and serotype analysis. Arch Virol 1996; 141: 715- 26.

[42] Rao CD, Jagannath MR., Varshney BC, Das M, Reddy BSY. In: Kobayashi N. Ed. Genomic diversity and molecular epidemiology of rotaviruses, Trivendrum; Research Signpost 2003; 55-74.

[43] Das M, Dunn SJ, Woode GN, Greenberg HB, Rao CD. Both surface proteins (VP4 and VP7) of an asymptomatic neonatal rotavirus strain (I321) have high levels of sequence identity with the homologous proteins of a serotype 10 bovine rotavirus. Virology 1993; 194: 374-9.

[44] Gentsch JR, Das BK, Jiang B, Bhan MK, Glass RI. Similarity of the VP4 protein of human rotavirus strain $116 \mathrm{E}$ to that of the bovine B223 strain. Virology 1993; 194: 424-30.
[45] Iturriza-Gomara MI, Kang G, Mammen A, et al. Characterization of $\mathrm{G} 10 \mathrm{P}[11]$ rotaviruses causing acute gastroenteritis in neonates and infants in Vellore, India. J Clin Microbiol 2004; 42: 2541-7.

[46] Karas M, Hillenkamp F. Laser desorption ionization of proteins with molecular masses exceeding 10000 Daltons. Anal Chem 1988; 60: 2299-301.

[47] Naiki H, Higuchi K, Hosokawa M, Takeda T. Fluorometric determination of amyloid fibrils in vivo using the fluorescent dye, thioflavin T. Anal Biochem 1989; 177: 244-9.

[48] Andrade MA, Chacon P, Merelo JJ, Moran F. Evaluation of secondary structure of proteins from UV circular dichroism using an unsupervised learning neural network. Protein Eng 1993; 6: 38390.

[49] Schagger H, von Jagaw G. Tricine-sodium dodecyl sulfatepolyacrylamide gel electrophoresis for the separation of proteins in the range of 1 to $100 \mathrm{kDa}$. Anal Biochem 1987; 166: 368-79.

[50] Blanchard BJ, Chen A, Rozeboom LM, Stafford KA, Weigele P, Ingram VM. Efficient reversal of Alzheimer's disease fibril formation and elimination neurotoxocity by a small molecule. Proc Natl Acad Sci USA 2004; 101: 14326-32.

[51] Devlin GL, Chow MKM, Howlett GJ, Bottomley SP. Acid denaturation of $\alpha 1$-antitrypsin: characterization of a novel mechanism of serpin polymerization. J Mol Biol 2002; 324: 85970 .

[52] Ferrari GV, Mallender WD, Inestrosa NC, Rosenberry TL. Thioflavin $\mathrm{T}$ is a fluorescent probe of the acetylcholinesterase peripheral site that reveals conformational interactions between the peripheral and acylation sites. J Biol Chem 2001; 276: 23282-7.

[53] Mirazimi A, Nilsson M, Svensson L. The molecular chaperone calnexin interacts with the NSP4 enterotoxin of rotavirus in vivo and in vitro. J Virol 1998; 72: 8705-9.

[54] Xu A, Bellamy AR, Taylor JA. Immobilization of the early secretory pathway by a virus glycoprotein that binds to microtubules. EMBO J 2000; 19: 6465-74.

[55] Boshuizen JA, Rossen JW, Sitaram CK, et al. Rotavirus enterotoxin NSP4 binds to the extracellular matrix proteins laminin-beta3 and fibronectin. J Virol 2004; 78: 10045-53.

[56] Parr RD, Storey SM, Mitchell DM, et al. The rotavirus enterotoxin NSP4 directly interacts with the caveolar structural protein caveolin-1. J Virol 2006; 80: 2842-54

[57] Seo N-S, Zeng CQ-Y, Hyser JM, et al. Integrins $\alpha 1 \beta 1$ and $\alpha 2 \beta 1$ are receptors for the rotavirus enterotoxin. Proc Natl Acad Sci USA 2008; 105: 8811-8

[58] Dong Y, Zeng CQ-Y, Ball JM, Estes MK, Morris AP. The rotavirus enterotoxin mobilizes intracellular calcium in human intestinal cells by stimulating phospholipase $\mathrm{C}$ mediated inositol 1 , 4, 5-triphosphate production. Proc Natl Acad Sci USA 1997; 94: 3960-5.

[59] Tian P, Estes MK, Hu Y, Ball JM, Zeng CQ, Schilling WP. The rotavirus nonstructural glycoprotein NSP4 mobilizes $\mathrm{Ca}^{2+}$ from the endoplasmic reticulum. J Virol 1994; 69: 5763-72.

[60] Berkova Z, Crawford SE, Trugnan G, Yoshimori T, Morris AP, Estes MK. Rotavirus NSP4 induces a novel vesicular compartment regulated by calcium and associated with viroplasms. J Virol 2006; 80: 6061-71.

[61] Newton K, Meyer JC, Bellamy AR, Taylor JA. Rotavirus nonstructural glycoprotein NSP4 alters plasma membrane permeability in mammalian cells. J Virol 1997; 71: 9458-65.

[62] Tian P, Ball JM, Zeng CQ, Estes MK. The rotavirus nonstructural glycoprotein NSP4 possesses membrane destabilization activity. J Virol 1996; 70: 6973-81.

[63] Beau I, Cotte-Lafitte J, Geniteau-Legendre M, Estes MK. An NSP4-dependent mechanism by which rotavirus impairs lactase enzymatic activity in brush border of human enterocyte-like Caco-2 cells. Cell Microbiol 2007; 9: 2254-66.

[64] Berkova Z, Crawford SE, Blatt SE, Morris AP, Estes MK. Expression of rotavirus NSP4 alters the actin network organization through the actin remodeling protein cofilin. J Virol 2007; 81: 3545-53.

[65] Martin-Latil S, Cotte-Laffitte J, Beau I, Wuero AM, GeniteauLegendre M, Servin AL. A cyclic AMP protein kinase Adependent mechanism by which rotavirus impairs the expression and enzyme activity of brush border-associated sucrase-isomaltase in differentiated intestinal Caco-2 cells. Cell Microbiol 2004; 6: 719-31. 
[66] Halaihel N, Lieven V, Ball JM, Estes MK, Alvarado F, Vasseur M. Direct inhibitory effect of rotavirus NSP4(114-135) peptide on the $\mathrm{Na}(+)$-D-glucose symporter of rabbit intestinal brush border membrane. J Virol 2000; 74: 9464-70.
[67] Ousingsawat J, Mirza M, Tian Y, et al. Rotavirus toxin NSP4 induces diarrhea by activation of TMEM16A and inhibition of $\mathrm{Na}^{+}$ absorption. Pflugers Arch-Eur J Physiol 2011; 461: 579-89.

(C) Sastri et al.; Licensee Bentham Open.

This is an open access article licensed under the terms of the Creative Commons Attribution Non-Commercial License (http: //creativecommons.org/licenses/by-nc/ $3.0 /$ ) which permits unrestricted, non-commercial use, distribution and reproduction in any medium, provided the work is properly cited. 